\title{
$1 \quad$ Late Cretaceous winter sea ice in Antarctica?
}

2 Vanessa C. Bowman ${ }^{1}$, Jane E. Francis ${ }^{1}$, James B. Riding ${ }^{2}$

$3 \quad{ }^{1}$ School of Earth and Environment, University of Leeds, Leeds, LS2 9JT, UK

$4 \quad{ }^{2}$ British Geological Survey, Keyworth, Nottingham, NG12 5GG, UK

5

6 Email: V.C.Bowman@leeds.ac.uk

7

\section{ABSTRACT}

9 The Late Cretaceous is generally considered to have been a time of greenhouse climate,

10 with no direct geological evidence for glaciation. We present, indirect evidence from the

11 Maastrichtian sedimentary record for significant, rapid sea-level changes suggests that

12 ice sheets were growing and decaying on Antarctica at that time. Evidence for possible

13 seasonal sea ice during the Maastrichtian [?largely] derives from the palynomorph

14 record of Seymour Island, Antarctica. The small, spine-bearing dinoflagellate cyst

15 Impletosphaeridium clavus is dominant, accounting for up to $99 \%$ of the marine

16 palynoflora. Its profusion is interpreted as the accumulation of resting cysts from

17 dinoflagellate blooms associated with winter sea ice decay. Peaks and lows of

18 Impletosphaeridium clavus abundance represent particularly cold episodes caused by

19 temporary stratification of polar waters, interposed with warmer periods when the

20 ocean was well-mixed. Immediately prior to the Cretaceous-Paleogene boundary,

21 Impletosphaeridium clavus decreased dramatically in abundance, interpreted to

22 represent an early expression of warming associated with Deccan Traps volcanism.

23 Terrestrial conditions inferred from spore/pollen data are consistent with the climate

24 interpretations based on Impletosphaeridium clavus, and together provide the highest

25 southern paleolatitude expression of global climate during the Maastrichtian. These 
palynomorph data, [?]together with $\delta^{18} \mathrm{O}$ values from macrofossils, support the

presence of ephemeral ice sheets on Antarctica during the Late Cretaceous, and

highlight the extreme sensitivity of this region to global climate change.

INTRODUCTION

Following peak warming during the Cretaceous (Turonian) Thermal Maximum (Wilson et al., 2002), global climates cooled during the latest Cretaceous (Friedrich et al., 2012). The well-established, rapid and significant sea level falls at this time requires the [controversial] presence of ephemeral ice sheets on Antarctica (Miller et al., 2005). There is no geological evidence, such as glacial tillites or ice-rafted debris (IRD), of glaciation during the Maastrichtian. Paleobotanical evidence, however, indicates significant cooling in the Antarctic Peninsula region (Francis and Poole, 2002). Here we present new evidence of Maastrichtian climates at $65^{\circ} \mathrm{S}$ based on palynology, including evidence of particularly cold episodes, using the dinoflagellate cyst Impletosphaeridium clavus Wrenn and Hart,1988 emend. Bowman et al. 2013 as a proxy. We present the first high-resolution, quantitative Maastrichtian to Danian palynomorph dataset from Seymour Island, off the northeast tip of the Antarctic Peninsula (Fig. 1). This is the highest southern paleolatitude exposure of sediments of this age in the world.

\section{METHODOLOGY}

A $~ 1100 \mathrm{~m}$ stratigraphic section comprising homogenous, unconsolidated silty-clays and clayey-silts was measured and sampled at high resolution (i.e. every 0.5 to $2 \mathrm{~m}$ ) throughout the continuous outcrop of the López de Bertodano Formation (LDBF) on Seymour Island (Figs. 1, 2). Eighty-one sediment samples were quantitatively processed for palynomorphs

50 throughout (Table DR1). The age of the section is Maastrichtian to earliest Danian based on 
magnetostratigraphy and strontium isotope stratigraphy (McArthur et al., 1998; Tobin et al., 2012). Macrofossil, microfossil and palynomorph evidence together with an iridium anomaly at the Cretaceous-Paleogene $(\mathrm{K} / \mathrm{Pg})$ boundary support this age model (Elliot et al., 1994; Olivero, 2011; Bowman et al., 2012; Table DR2). Numerical ages herein are based on Gradstein et al. (2012), which place the $\mathrm{K} / \mathrm{Pg}$ boundary at $66.0 \mathrm{Ma}$; this is at $1007.5 \mathrm{~m}$ in our section.

\section{RESULTS}

Dinoflagellate cysts and acritarchs comprise, on average, $70 \%$ of the palynofloras below horizon $\mathrm{G}$ at $830 \mathrm{~m}$ (Table DR1). The small, spine-bearing dinoflagellate cyst Impletosphaeridium clavus is dominant, representing up to $99 \%$ of the marine palynofloras and attaining up to $\sim 137,000$ specimens per gram of sediment. The palynomorph record has been divided by five horizons (A, C, E, G and I; Fig 2) into five intervals (B, D, F, H and J; Fig. 2). Below $830 \mathrm{~m}$, three conspicuous abundance peaks of Impletosphaeridium clavus are recorded at horizons $\mathrm{A}, \mathrm{C}$ and $\mathrm{E}$ (143 m, $407 \mathrm{~m}$ and $746 \mathrm{~m}$ respectively), with intervening intervals of lower concentrations (B, D and F, Fig. 2). The remainder of the marine palynoflora includes typical South Polar Province dinoflagellate cyst genera, such as Manumiella spp. (Bowman et al., 2012). Within the same facies, this fluctuating pattern ends abruptly at horizon $\mathrm{G}$ with the concentration of Impletosphaeridium clavus decreasing to only hundreds of specimens per gram of sediment above $830 \mathrm{~m}$. Impletosphaeridium clavus increases again in abundance immediately below the $\mathrm{K} / \mathrm{Pg}$ boundary, but at relatively low concentrations compared with the lower part of the section. palynoflora, Table DR1), coincident with the abrupt decrease in concentration of 
antiquasporites (moss) spores, together with Nothofagidites spp. (southern beech), Peninsulapollis gillii (Proteaceae), Phyllocladidites mawsonii and Podocarpidites spp. (podocarp conifers) pollen dominate throughout, with rare aquatic fern spores (e.g. Azolla spp.) and freshwater algae (e.g. Botryococcus braunii). Nothofagidites spp. pollen is more abundant and fungal palynomorphs absent at the Impletosphaeridium clavus peaks. The distinctive angiosperm pollen species Tricolpites reticulatus (Gunneraceae), Clavamonocolpites polygonalis (?Chloranthaceae) and Ericipites scabratus (Ericaceae) occur rarely between Impletosphaeridium clavus peaks $\mathrm{A}$ and $\mathrm{C}$, and between peak $\mathrm{E}$ and the $\mathrm{K} / \mathrm{Pg}$ boundary (Figs. 2 and DR1).

\section{DISCUSSION}

Evidence from neodymium isotopes suggests that deep-water formation, and consequent mixing of the water column, began in the Southern Ocean during the Campanian (Robinson et al., 2010). A relatively mixed water column at this time is supported by a lower planktic to benthic oxygen-isotope gradient during the Maastrichtian compared with the Cenomanian (Huber et al., 2002). Density-driven overturning and wind-driven upwelling, as in the modern Southern Ocean, would have ventilated the entire water column (Mitchell et al., 1991; Sigman et al., 2004). This scenario of a mixed, oxygen and nutrient-rich water column provides the setting for any oceanic change at the Antarctic margin during the Maastrichtian, and may have been the contextual state of the ocean represented by intervals B, D and possibly F in the Impletosphaeridium clavus record from Seymour Island (Fig. 2).

The acmes of Impletosphaeridium clavus at A, C and E (Fig. 2) project from the background levels below $830 \mathrm{~m}$, and are interpreted as reflecting accumulations of resting cysts during periods (lasting perhaps tens of thousands of years) of enhanced seasonal bloom activity (rapid population increases) of the parent dinoflagellates. Dinoflagellate blooms 
101 occur today in freshwater and marine coastal environments of the low to mid latitudes in response to enhanced nutrient levels and temperature-driven stratification, primarily during

103 the late spring to early summer (Stipa, 2002; Kudela et al., 2005; Michalak et al., 2013).

104 Dinoflagellate blooms are also known to occur in the modern high northern and southern

105 latitudes associated with the melting of seasonal sea ice, followed by the production of vast

106 quantities of resting cysts (Becquevort et al., 1992; Stoecker et al., 1992). These abundant

107 cysts then fall to the sea floor when the ice melts in late spring or early summer (Harland and 108 Pudsey, 1999).

109 To investigate the striking abundance pattern of Impletosphaeridium clavus during the

110 Maastrichtian off the Antarctic margin, we studied geochemical and additional palynofloral

111 data from Seymour Island (Fig. 2). Tobin et al.'s (2012) $\delta^{18} \mathrm{O}$ values from macrofossils

112 correlate remarkably well, showing an increase through interval D, then decrease through

113 intervals $\mathrm{F}$ and $\mathrm{H}$, mirroring the Impletosphaeridium clavus record (Fig. 2). This close

114 correlation of Tobin et al.'s (2012) data with our palynomorph data further strengthens our

115 age model. Overall, heavier $\delta^{18} \mathrm{O}$ values correspond to periods of higher abundance of

116 Impletosphaeridium clavus (particularly at horizon E, Fig. 2). We infer from this conformity

117 of pattern that blooms of the dinoflagellate that produced the resting cyst Impletosphaeridium

118 clavus occurred during periods of particularly cool benthic and intermediate water off the

119 Antarctic Peninsula region during the Maastrichtian.

120 No other marine (or terrestrial) palynomorph exhibits a similar abundance pattern to

121 Impletosphaeridium clavus (e.g. Thorn et al., 2009), which suggests that there is a unique

122 environmental factor (not otherwise recorded in the sedimentary record), influencing the

123 success of the dinoflagellate that produced this cyst. We infer from the close correlation of

124 the $\delta^{18} \mathrm{O}$ record that it preferred cool to cold water temperatures, and may even have tolerated

125 near-freezing conditions based on Tobin et al.'s (2012) lowest annually-averaged estimate of 
$126 \sim 4-5^{\circ} \mathrm{C}$, close to the Impletosphaeridium clavus acme at horizon E. In addition, $\delta^{18} \mathrm{O}$

127 measurements from a belemnite (Dimitobelus seymouriensis Doyle and Zinsmeister 1988)

128 correlate to our section immediately below the Impletosphaeridium clavus acme at horizon C

129 (open arrow “c”, Fig. 2). This suggests a similar intermediate to deep-water mean annual

130 temperature of a cool $6^{\circ} \mathrm{C}$ at this level with an average annual variability of $5^{\circ} \mathrm{C}$ (Dutton et

131 al., 2007). These cool intermediate and benthic water temperatures are derived from average annual $\delta^{18} \mathrm{O}$ isotope values, and do not preclude surface water temperatures, especially during the Antarctic winter, dropping below freezing and supporting sea ice development.

134 We infer that the most likely explanation for dinoflagellate blooms in cold, generally well-

135 mixed, shallow marine waters at the Antarctic margin is that they occurred in association

136 with the melting of seasonal sea ice. Although there is no direct modern analogue of

137 Impletosphaeridium clavus (Bowman et al., 2013), unsurprising for a cyst from the Late

138 Cretaceous, there are many taxa of small spiny cysts, all comparable in gross morphology,

139 known from sea ice, modern and Quaternary sediment in cold environments of the high

140 southern and northern latitudes (Buck et al., 1992; Stoecker et al., 1992, 1997; Head et al.,

141 2001; Radi et al., 2013). Several of these are characteristic of regions where seasonal sea ice

142 forms (e.g. Islandinium? cezare (de Vernal et al. 1989 ex de Vernal in Rochon et al. 1999)

143 Head et al. 2001; Fig. 2) and, comparable to the abundance record of Impletosphaeridium

144 clavus presented here, some can dominate up to $90 \%$ of marine palynomorph assemblages

145 (De Vernal and Rochon, 2011; Radi et al., 2013). The dinoflagellate that produced

146 Impletosphaeridium clavus may have had a similar life strategy to that of modern Biecheleria

147 baltica Moestrup et al. 2009, a brackish water dinoflagellate (also with a small, spiny resting

148 cyst) associated with sea ice cover in the Baltic Sea (Klais et al., 2011; Warns et al., 2012).

149 Biecheleria baltica produces vast quantities of resting cysts, which accumulate in benthic 
cyst beds (at relatively shallow water depths) and promote intense spring blooms by the motile seeding of the euphotic zone (Klais et al., 2011).

The reconstruction of pre-Quaternary sea ice from the fossil record in both the Arctic and Antarctic has previously relied on the modern analogue interpretation of Leiosphaeridia spp. acritarchs, diatoms, foraminifera and terrigenous IRD (St. John, 2008; Davies et al., 2009; Stickley et al., 2009). Diatoms and foraminifera are sparse in the LDBF (e.g. Harwood, 1988). However, the lack of diatoms characteristic of sea ice in the fossil record may be due to a specific paleoecological scenario. For example, early salinity stratification in the modern Baltic Sea favors dinoflagellates over diatoms in the spring blooms associated with sea ice retreat (Klais et al., 2011). No Leiosphaeridia spp. or indisputable IRD were recorded from

160 the LDBF. Leiosphaeridia spp., which has been used as a proxy for sea ice in the Neogene of 161 Antarctica by Hannah (2006), is present in the Campanian of Humps Island (Wood and Askin, 1992) and may suggest the presence of sea ice in the Antarctic Peninsula region even earlier in the Cretaceous. Habitat difference, e.g. water depth, nutrient availability or levels of

164 oxygenation, may explain their absence in the Maastrichtian record of Seymour Island 165 (Jacobson, 1979).

The lack of IRD in our section is perhaps understandable because, based on the presence

167 of diverse and abundant terrestrial palynomorphs (Askin, 1990), the nearest landmass was vegetated and distant from any potential ice caps at high elevations in the Antarctic

169 continental interior. If sea ice was present it may not have been land-fast, preventing the 170 entrainment of out-sized terrigenous IRD. Manoj et al. (2013) noted that IRD is largely 171 absent in the Holocene of the Indian sector of the Southern Ocean, inferring that this is a result (as in past interglacials) of ice sheet accumulation being mainly restricted to high continental interiors. Similarly, and perhaps for the same reasons, no direct evidence of ice 
174 from Late Cretaceous sediments was recovered from Ocean Drilling Program Leg 113 cores

175 in the Weddell Sea (Kennett and Barker, 1990).

176 If, as we contend, fossil Impletosphaeridium clavus abundances may be used as a proxy

177 for seasonal sea ice, an explanation is required for the episodic, vast accumulations of this

178 cyst that peak at horizons A, C and E (Fig. 2). Dinoflagellates bloom today at the retreating

179 sea ice margin, so variation in the accumulation of fossil resting cysts through geological

180 time in the LDBF must reflect an overprint of an additional longer-term climate or habitat

181 change. One suggestion is these periods of enhanced production of resting cysts may reflect

182 particularly cold climatic phases where the water column became more stratified on the

183 shallow marine shelf, as suggested for deeper waters in the Southern Ocean during the

184 Pliocene (Sigman et al., 2004). These phases, straddling the Impletosphaeridium clavus

185 abundance peaks, perhaps lasted tens of thousands of years, and may reflect variations in

186 orbital cyclicity. [agreed - it is a tad speculative - JBR]

187 On the LDBF shelf, which had a slightly fresher surface layer due to riverine inflow, a

188 climatic cooling may have diminished the influence of background temperature-driven

189 mixing, thereby allowing the establishment of a more stable water column in the basin

190 influenced by salinity stratification. During the spring, the formation of an oxygen-rich

191 surface layer, with increased light levels (due to less mixing), and nutrients replenished via

192 buoyant terrestrial inflow and the sea ice melt, would have promoted monospecific blooms of

193 habitat-specific dinoflagellates. Dinoflagellates would still have bloomed during sea ice

194 retreat between these colder spells (i.e. during the middle of intervals B, D and F, Fig. 2), but

195 with less stratification, the light levels would have been lower and the incoming nutrients

196 more diluted throughout the water column, resulting in lower numbers of dinoflagellates and

197 their resting cysts. 
Additional evidence for Maastrichtian climatic change comes from the terrestrial palynomorph record of Seymour Island, which indicates that the region was forested with southern beech (Nothofagus spp.) and conifers (mainly Podocarpidites spp.). Most modern relatives of the southern beech grow in wet, cool to cold environments (Read et al., 2010).

202 Below the K/Pg boundary, Nothofagidites spp. abundance was lowest during phase $\mathrm{H}$ and 203 highest below G, peaking alongside the Impletosphaeridium clavus acmes at horizons A, C and E (Fig. 2, Table DR1). By contrast, Nothofagidites spp. abundance was lower, although variable, in the intervening warmer phases B and D (Fig. 2). Furthermore, pollen representing specific thermophylic plants such as Gunneraceae (Tricolpites reticulatus) appears first

207 during warmer phase $\mathrm{B}$, and much more frequently above horizon $\mathrm{E}$ as the region warmed 208 again towards the latest Maastrichtian (Fig. 2, Table DR3). The presence of fungal remains during warm phases B and D, their absence during cold episodes A, C and E, and their

210 increase in frequency of occurrence following E supports evidence for pre-K/Pg warming

211 (Fig. 2). This is consistent with an increase in saprophytic degradation of the terrestrial

212 biomass which grew during the warmer climate. In addition, from the marine macrofossil

213 record, the restricted stratigraphic occurrences of the belemnite Dimitobelus seymouriensis

214 Doyle 1988 and the ammonite Zelandites varuna Forbes 1846 support our interpretation of

215 short-term warmer intervals (Zinsmeister, 2001; Fig. 2).

216 Previous research supports a generally cool climate in this region during the

217 Maastrichtian. Dicotyledonous wood analysis suggests mean annual terrestrial temperatures

218 of $7^{\circ} \mathrm{C}$ (Francis and Poole, 2002) and marine molluscan extinction patterns indicate

219 Campanian to Maastrichtian cooling associated with regional shallowing (Crame et al., 1996). Additionally, chemical weathering and sediment maturity suggest probable cold

221 temperate or sub-polar conditions for the Antarctic interior during the Maastrichtian (Dingle 222 and Lavelle, 1998). 
With no change in facies, the abrupt decrease in abundance of Impletosphaeridium clavus across horizon $\mathrm{G}$ in the LDBF is interpreted as representing rapid warming that lasted until the $\mathrm{K} / \mathrm{Pg}$ boundary, which prevented the build-up of winter ice in the northern Antarctic Peninsula region. This coincides with lower abundances of Nothofagidites spp. and an increase in the occurrence of thermophylic plants and saprophytic fungal remains through phase $\mathrm{H}$, all suggesting warming. Impletosphaeridium clavus increases again in abundance across the K/Pg boundary, but irregularly and in low numbers. Similarly, Nothofagidites spp. again increases in abundance into the Danian. This may indicate slight cooling associated with disturbed environments and an erratic recovery period from the $\mathrm{K} / \mathrm{Pg}$ catastrophe.

The palynomorph record from the LDBF of Seymour Island strongly suggests a pattern of at least three particularly cold episodes during the Maastrichtian, followed by an abrupt warming immediately prior to the $\mathrm{K} / \mathrm{Pg}$ event. This is consistent with other records of Maastrichtian climate trends, which indicate overall cooling until a sudden warming before the K/Pg boundary (Barrera and Savin, 1999; Abramovich and Keller, 2003). From the mid Campanian to $\sim 500 \mathrm{ka}$ prior to the $\mathrm{K} / \mathrm{Pg}$ boundary, oxygen and carbon isotope excursions indicate two significant cooling episodes (Barrera and Savin, 1999; Friedrich et al., 2012) superimposed on a long-term cooling trend of intermediate waters, particularly in the high latitudes. The first of these, the Campanian-Maastrichtian Boundary Event (CMBE, base of

$241 \mathrm{C} 32 \mathrm{~N} 1$ to upper $\mathrm{C} 31 \mathrm{R})$, is characterized by a significant global negative carbon isotope 242 excursion, associated with climatic cooling and sea level fall (Friedrich et al., 2009; Jung et 243 al., 2012). Based on magnetostratigraphy, the end of the CMBE correlates with the lower $244 \sim 500 \mathrm{~m}$ of our section, encompassing the cold episodes interpreted at horizons A and C (Fig. 2). The second cooling episode recognized from the deep sea occurred from uppermost $\mathrm{C} 31 \mathrm{~N}$ 246 to the top of C30N (Barrera and Savin, 1999) bracketing the final Impletosphaeridium clavus

247 acme during the Maastrichtian (horizon E, Fig. 2). The causes of these oceanic cool phases 
remain controversial; they have been related to short-term changes in thermohaline circulation and/or the development of ephemeral ice sheets on Antarctica in association with global regressions (Miller et al., 2005; Koch and Friedrich, 2012). Further evidence supporting intervening warmer phases comes from $\delta^{13} \mathrm{C}$ and $\delta^{18} \mathrm{O}$ analysis of paleosol carbonates (Nordt et al., 2003; correlated to interval B, Fig. 2) and bulk carbonate (Voigt et al., 2012; interval D, Fig. 2).

The earliest records of abundant Impletosphaeridium clavus in the James Ross Basin supports the timing of the onset of cold climates in Antarctica during the Campanian evidenced by neodymium isotopes, and the coeval extinction of inoceramid bivalves (Dolding, 1992; Crame and Luther, 1997; Robinson et al., 2010; Bowman et al., 2013). The switch to deep-water production at the Antarctic margin at this time (Robinson et al., 2010) strengthens the link made here between abundant Impletosphaeridium clavus and the presence of seasonal sea ice in the Cretaceous because the formation of cold deep waters on the Antarctic shelf today is intrinsically linked to winter sea ice formation (Withworth et al., 262 1998).

Our data interpretations suggest climate may have been cold enough periodically to initiate short-term glaciations of Antarctica, probably restricted to high elevations in the continental interior, during the Maastrichtian. Modeling exploring Cenozoic glaciation corroborates this theory by predicting that significant sea ice forms only in the Southern

267 Ocean after the initiation of ice sheets in central Antarctica (DeConto et al., 2007). Hong and 268 Lee (2012) concurred that the Maastrichtian was cold enough to have allowed Antarctic glaciation using estimates of $\mathrm{pCO} 2$ levels below $500 \mathrm{ppm}$ from low latitude pedogenic carbonates.

271 Analysis of our data suggests that a latest Maastrichtian climatic warming (beginning after

272 horizon E, Fig. 2) probably prevented the survival of seasonal sea ice at this paleolatitude, 
even in the coldest winters. One explanation for this is that at the Antarctic margin, $\sim 2 \mathrm{Ma}$

274 prior to the $\mathrm{K} / \mathrm{Pg}$ boundary, the marine and terrestrial fossil record has recorded the beginning

275 of a latest Maastrichtian greenhouse event. Globally, warming through $\sim 500$ ka prior to the

$276 \mathrm{~K} / \mathrm{Pg}$ boundary, has been attributed to outgassing associated with the main pulse of Deccan

277 Traps volcanism (Barrera and Savin, 1999; Abramovich and Keller, 2003; Nordt et al., 2003).

278 The earliest (albeit minor) eruptive phase of Deccan Traps volcanism began at the base of

279 C30N (Chenet et al., 2009), coincident with significant changes in the fossil record on

280 Seymour Island. At this level, the final decline in Impletosphaeridium clavus numbers began

281 prior to the K/Pg boundary, Nothofagidites spp. pollen abundance began to decrease, warmth-

282 loving angiosperm taxa suddenly appeared, saprophytic fungal spores became more prevalent

283 and a decrease in $\delta^{18} \mathrm{O}$ isotope values from macrofossils occurred (Tobin et al., 2012) (Fig.

284 2). We contend that our data from this expanded Maastrichtian section highlight the extreme

285 sensitivity of the Antarctic paleoenvironment to global climatic change.

286

287 CONCLUSIONS

288 We provide the first evidence endorsing the presence of seasonal sea ice during the Late

289 Cretaceous at the Antarctic margin. The profusion of Impletosphaeridium clavus from the

290 Maastrichtian succession of Seymour Island is considered to represent dinoflagellate blooms

291 and subsequent accumulation of their resting cysts related to winter sea ice decay, much like

292 those produced in abundance today by sea ice dinoflagellates in the Southern Ocean. We

293 consider this as a novel potential proxy for seasonal sea ice and thus Antarctic paleoclimate.

294 Superimposed on a cooling Maastrichtian climate and a generally well-mixed water column,

295 Impletosphaeridium clavus acmes suggest particularly cold episodes during temporary

296 stratification of shallow marine waters, interposed with slightly warmer periods when

297 temperature-driven mixing was re-established. Climate interpretations of the terrestrial 
298 palynomorph record and $\delta^{18} \mathrm{O}$ isotope analyses from macrofossils support these

299 interpretations. Based on our age model, the palynomorph record herein represents the

300 highest southern paleolatitude expression of global Maastrichtian climate events, including

301 evidence for the end of cooling and perhaps early expression of warming in the latest

302 Cretaceous associated with Deccan Traps volcanism. The Seymour Island palynomorph

303 record of seasonal sea ice for most of the Maastrichtian, in turn, strongly supports year-round

304 glaciation at elevation in the interior of the continent. This agrees with the controversial

305 notion of ephemeral Late Cretaceous ice caps on Antarctica as a causal mechanism for

306 eustatic change and highlights the extreme sensitivity of the high southern paleolatitudes to

307 global climate change.

308

309

ACKNOWLEDGMENTS

310 We thank J.A. Crame, A.M. Haywood, S.J. Hunter, J. Witts and R. Raiswell for discussions,

311 and the British Antarctic Survey and HMS Endurance for logistics during Antarctic

312 fieldwork. Crispin Day, Bruce Mortman and Matt Priestman provided field support. This

313 work was funded by a Natural Environment Research Council (NERC) Antarctic Funding

314 Initiative project (Grant NE/C506399/1). VCB received additional funds from the

315 TransAntarctic Association and an Antarctic Science Bursary. JBR publishes with the

316 approval of the Executive Director, British Geological Survey (NERC).

\section{REFERENCES CITED}

319 Abramovich, S., and Keller, G., 2003, Planktonic foraminiferal response to the latest

320 Maastrichtian abrupt warm event: a case study from South Atlantic DSDP Site 525A:

321 Marine Micropaleontology, v. 48, p. 225-249.

322 Askin, R.A., 1990, Campanian to Paleocene spore and pollen assemblages of Seymour

323 Island, Antarctica: Review of Palaeobotany and Palynology, v. 65, p. 105-113. 
325 Barrera, E., and Savin, S.M., 1999, Evolution of late Campanian - Maastrichtian marine

326 climates and oceans: Geological Society of America Special Paper, v. 332, p. 245-282.

327 Becquevort, S., Mathot, S., and Lancelot, C., 1992, Interactions in the microbial community

328 of the marginal ice zone of the northwestern Weddell Sea through size distribution analysis: Polar Biology, v. 12, p. 211-218.

Bowman, V.C., Francis, J.E., Riding, J.B., Hunter, S.J., and Haywood, A.M., 2012, A latest Cretaceous to earliest Paleogene dinoflagellate cyst zonation from Antarctica, and implications for phytoprovincialism in the high southern latitudes: Review of Palaeobotany and Palynology, v. 171, p. 40-56.

Bowman, V.C., Riding, J.B., Francis, J.E., Crame, J.A., and Hannah, M.J., 2013, The taxonomy and palaeobiogeography of small chorate dinoflagellate cysts from the Late Cretaceous to Quaternary of Antarctica: Palynology, doi: $10.1080 / 01916122.2012 .750898$.

Buck, K.R., Bolt, P.A., Bentham, W.N., and Garrison, D.L., 1992, A dinoflagellate cyst from Antarctic sea ice: Journal of Phycology, v. 28, p.15-18.

340 Chenet, A.-L., Quidelleur, X., Fluteau, F., Courtillot, V., and Bajpai, S., 2007, ${ }^{40} \mathrm{~K}-{ }^{40} \mathrm{Ar}$

341 dating of the main Deccan large igneous province: further evidence of KTB age and 342 short duration: Earth and Planetary Science Letters, v. 263, p. 1-15.

343 Chenet, A.-L., Courtillot, V., Fluteau, F., Gérard, M., Quidelleur, X., Khadri, S.F.R., 344 Subbarao, K.V., and Thordarson, T., 2009, Determination of rapid Deccan eruptions across the Cretaceous-Tertiary boundary using paleomagnetic secular variation: 2 .

346 Constraints from analysis of eight new sections and synthesis for a 3500-m-thick

347 composite section: Journal of Geophysical Research, v. 114, B06103, doi: 10.1029/2008JB005644. 
349 Crame, J.A., and Luther, A., 1997, The last inoceramid bivalves in Antarctica: Cretaceous $350 \quad$ Research, v. 18, p. 179-195.

351 Crame, J.A., Lomas, S.A., Pirrie, D., and Luther, A., 1996, Late Cretaceous extinction 352 patterns in Antarctica: Journal of the Geological Society, v. 153, p. 503-506.

353 Davies, A., Kemp, A.E.S., and Pike, J., 2009, Late Cretaceous seasonal ocean variability 354 from the Arctic: Nature, v. 460, p. 254-258.

355 De Vernal, A., and Rochon, A., 2011, Dinocysts as tracers of sea-surface conditions and seaice cover in polar and subpolar environments: IOP Conference Series: Earth and Environmental Science, v. 14, 012007 (doi:10.1088/1755-1315/14/1/012007), 12 p.

DeConto, R., Pollard, D., and Harwood, D., 2007, Sea ice feedback and Cenozoic evolution of Antarctic climate and ice sheets: Paleoceanography, v. 22, PA3214, doi:

Dingle, R.V., and Lavelle, M., 1998, Late Cretaceous-Cenozoic climatic variations of the northern Antarctic Peninsula: new geochemical evidence and review: Palaeogeography, Palaeoclimatology, Palaeoecology, v. 141, p. 215-232.

Dolding, P.J.D., 1992, Palynology of the Marambio Group (Upper Cretaceous) of northern Humps Island: Antarctic Science, v. 4, no. 3, p.311-326.

Doyle, P., and Zinsmeister, W.J., 1988, The new dimitobelid belemnite from the Upper Cretaceous of Seymour Island, Antarctic Peninsula, in Feldmann, R.M., and Woodburne,

Dutton, A., Huber, B.T., Lohmann, K.C., and Zinsmeister, W.J., 2007. High-resolution stable isotope profiles of a dimitobelid belemnite: implications for paleodepth habitat and late Maastrichtian climate seasonality: Palaios, v. 22, p. 642-650. 
373 Elliot, D.H., Askin, R.A., Kyte, F.T., and Zinsmeister, W.J., 1994, Iridium and dinocysts at 374 the Cretaceous-Tertiary boundary on Seymour Island, Antarctica: implications for the K375 T event: Geology, v. 22, p. 675-678.

376 Francis, J.E., and Poole, I., 2002, Cretaceous and early Tertiary climates of Antarctica: evidence from fossil wood: Palaeogeography, Palaeoclimatology, Palaeoecology, v. 182, p. 47-64.

Friedrich, O., Herrle, J.O., Wilson, P.A., Cooper, M.J., Erbacher, J., and Hemleben, C., 2009, Early Maastrichtian carbon cycle perturbation and cooling event: implications from the South Atlantic Ocean: Paleoceanography, v. 24, PA2211, doi:10.1029/2008PA001654.

Friedrich, O., Norris, R.D., and Erbacher, J., 2012, Evolution of middle to Late Cretaceous oceans - A 55 m.y. record of Earth's temperature and carbon cycle: Geology, v. 40, p. 107-110.

Gradstein, F.M., Ogg, J.G., Schmitz, M., and Ogg, G., 2012, The Geologic Time Scale 2012. Elsevier Science Limited, 1152 pp.

Hannah, M.J., 2006, The palynology of ODP site 1165, Prydz Bay, East Antarctica: a record of Miocene glacial advance and retreat: Palaeogeography, Palaeoclimatology,

Harland, R., and Pudsey, C.J., 1999, Dinoflagellate cysts from sediment traps deployed in the Bellingshausen, Weddell and Scotia Seas, Antarctica: Marine Micropaleontology, v. 37,

Harwood, D.M., 1988, Upper Cretaceous and lower Paleocene diatom and silicoflagellate biostratigraphy from Seymour Island, eastern Antarctic Peninsula, in Feldmann, R.M., and Woodburne, M.O., eds., The Geology and Paleontology of Seymour Island: Geological Society of America Memoir, v. 169, p. 55-130. 
Head, M.J., Harland, R., and Matthiessen, J., 2001, Cold marine indicators of the late Quaternary: the new dinoflagellate cyst genus Islandinium and related morphotypes: Journal of Quaternary Science, v. 16, p. 621-636.

Hong, S.K., and Lee, Y.I., 2012, Evaluation of atmospheric carbon dioxide concentrations during the Cretaceous: Earth and Planetary Science Letters, v. 327-328, p. 23-28.

Huber, B.T., Norris, R.D., and MacLeod, K.G., 2002. Deep-sea palaeotemperature record of extreme warmth during the Cretaceous: Geology, v. 30, p. 123-126.

Jacobson, S.R., 1979, Acritarchs as paleoenvironmental indicators in Middle and Upper Ordovician rocks from Kentucky, Ohio and New York: Journal of Paleontology, v. 53, p. 1197-1212.

Jung, C., Voigt, S., and Friedrich, O., 2012, High-resolution carbon-isotope stratigraphy across the Campanian-Maastrichtian boundary at Shatsky Rise (tropical Pacific): Cretaceous Research, v. 37, p. 177-185.

Kennett, J.P., and Barker, P.F., 1990, Latest Cretaceous to Cenozoic climate and oceanographic developments in the Weddell Sea, Antarctica: an ocean-drilling perspective, in Barker, P.F., Kennett, J.P., et al., eds., Proceedings of the Ocean Drilling Program: Scientific Results, v. 113, p. 937-960.

Koch, M.C., and Friedrich, O., 2012, Campanian-Maastrichtian intermediate- to deep-water changes in the high latitudes: benthic foraminiferal evidence: Paleoceanography, v. 27, PA2209, doi: 10.1029/2011PA002259. 
Manoj, M.C., Thamban, M., Sahana, A., Mohan, R., and Mahender, K., 2013, Provenance and temporal variability of ice rafted debris in the Indian sector of the Southern Ocean during the last 22,000 years: Journal of Earth System Science, v. 122, p. 491-501.

McArthur, J.M., Thirlwall, M.F., Engkilde, M., Zinsmeister, W.J., and Howarth, R.J., 1998, Strontium isotope profiles across K/T boundary sequences in Denmark and Antarctica: Earth and Planetary Science Letters, v. 160, p. 179-192.

Michalak, A.M., Anderson, E.J., Beletsky, D., Boland, S., Bosch, N.S., Bridgeman, T.B., Chaffin, J.D., Cho, K., Confesor, R., Daloğlu, I., DePinto, J.V., Evans, M.A., Fahnenstiel, G.L., He, L., Ho, J.C., Jenkins, L., Johengen, T.H., Kuo, K.C., LaPorte, E., Liu, X., McWilliams, M.R., Moore, M.R., Posselt, D.J., Richards, R.P., Scavia, D., Steiner, A.L., Verhamme, E., Wright, D.M., and Zagorski, M.A., 2013, Record-setting algal bloom in Lake Erie caused by agricultural and meteorological trends consistent with expected future conditions: PNAS, v. 110, p. 6448-6452.

Miller, K.G., Wright, J.D., and Browning, J.V., 2005, Visions of ice sheets in a greenhouse world: Marine Geology, v. 217, p. 215-231.

Nordt, L., Atchley, S., and Dworkin, S., 2003, Terrestrial evidence for two Greenhouse events in the latest Cretaceous: GSA Today, v. 13, no. 12, p. 4-9.

Olivero, E.B., 2011, Sedimentary cycles, ammonite diversity and palaeoenvironmental changes in the Upper Cretaceous Marambio Group, Antarctica: Cretaceous Research, v. 34, p. 348-366.

Radi, T., Bonnet, S., Cormier, M.-A., De Vernal, A., Durantou, L., Faubert, É, Head, M.J., Henry, M., Pospelova, V., Rochon, A., and Van Nieuwenhove, N., 2013, Operational taxonomy and (paleo-)autecology of round, brown, spiny dinoflagellate cysts from the Quaternary of high northern latitudes: Marine Micropaleontology, v. 98, p. 41-57. 
Read, J., Hill, R.S., Hope, G.S., and Carpenter, R.J., 2010, The contrasting biology of tropical versus temperate Nothofagus species and its relevance to interpretations of Cenozoic rainforest history in southeast Australia, in Haberle, S., Stevenson, J., and Prebble, M., eds., Altered Ecologies: Fire, climate and human influence on terrestrial landscapes: Terra Australis, ANU Press, v. 32, p. 15-32.

Robinson, N., Ravizza, G., Coccioni, R., Peucker-Ehrenbrink, B., and Norris, R., 2009. A high-resolution marine ${ }^{187} \mathrm{Os} /{ }^{188}$ Os record for the late Maastrichtian: distinguishing the chemical fingerprints of Deccan volcanism and the KP impact event: Earth and Planetary Science Letters, v. 281, p. 159-168.

Robinson, S.A., Murphy, D.P., Vance, D., and Thomas, D.J., 2010, Formation of "Southern Component Water" in the Late Cretaceous: evidence from Nd-isotopes: Geology, v. 38, p. $871-874$.

Sigman, D.M., Jaccard, S.L., and Haug, G.H., 2004, Polar ocean stratification in a cold climate: Nature, v. 428, p. 59-63.

St John, K., 2008, Cenozoic ice-rafting history of the central Arctic Ocean: terrigenous sands on the Lomonosov Ridge: Paleoceanography, v. 23, PA1S05, doi:10.1029/2007PA001483.

Stickley, C.E., St John, K., Koç, N., Jordan, R.W., Passchier, S., Pearce, R.B., and Kearns, L.E., 2009, Evidence for middle Eocene Arctic sea ice from diatoms and ice-rafted debris: Nature, v. 460, p. 376-379.

Stipa, T., 2002, Temperature as a passive isopycnal tracer in salty, spiceless oceans: Geophysical Research Letters, v. 29, doi: 10.1029/2001GL014532.

Stoecker, D.K., Buck, K.R., and Putt, M., 1992, Changes in the sea-ice brine community during the spring-summer transition, McMurdo Sound, Antarctica. I. Photosynthetic protists: Marine Ecology Progress Series, v. 84, p. 265-278. 
Stoecker, D.K., Gustafson, D.E., Merrell, J.R., Black, M.M.D., and Baier, C.T., 1997, Excystment and growth of chrysophytes and dinoflagellates at low temperatures and high salinities in Antarctic sea ice: Journal of Phycology, v. 33, 585-595.

Thorn, V.C., Riding, J.B., and Francis, J.E., 2009, The Late Cretaceous dinoflagellate cyst Manumiella - biostratigraphy, systematics, and palaeoecological signals in Antarctica: Review of Palaeobotany and Palynology, v. 156, p. 436-448.

Tobin, T.S., Ward, P.D., Steig, E.J., Olivero, E.B., Hilburn, I.A., Mitchell, R.N., Diamond, M.R., Raub, T.D., and Kirschvink, J.L., 2012, Extinction patterns, $\delta^{18} \mathrm{O}$ trends, and magnetostratigraphy from a southern high-latitude Cretaceous-Paleogene section: links with Deccan volcanism: Palaeogeography, Palaeoclimatology, Palaeoecology, v. 350352, p. $180-188$.

Voigt, S., Gale, A.S., Jung, C., and Jenkyns, H.C., 2012, Global correlation of Upper Campanian-Maastrichtian successions using carbon-isotope stratigraphy: development of a new Maastrichtian timescale: Newsletters on Stratigraphy, v. 45, p. 25-53.

Vonhof, H.B., Jagt, J.W.M., Immenhauser, A., Smit, J., Van den Berg, Y.W., Saher, M., Keutgen, N., and Reijmer, J.J.G., 2011, Belemnite-based strontium, carbon and oxygen isotope stratigraphy of the type area of the Maastrichtian Stage, in Jagt, J.W.M., JagtYazykova, E.A., and Schins, W.J.H., eds., A tribute to the late Felder brothers - pioneers of Limburg geology and prehistoric archaeology: Netherlands Journal of Geosciences, v. 90, p. $259-270$.

Warns, A., Hense, I., and Kremp, A., 2012, Modelling the life cycle of dinoflagellates: a case study with Biecheleria baltica: Journal of Plankton Research, v. 35, p. 379-392.

Wilson, P. A., Norris, R. D., Cooper, M. J., 2002, Testing the Cretaceous greenhouse hypothesis using glassy foraminiferal calcite from the core of the Turonian tropics on Demerara Rise: Geology, v. 30, p.607-610. 
Withworth, T. III, Orsi, A.H., Kim, S.-J., Nowlin, W.D. Jr., and Locarnini R.A., 1998, Water masses and mixing near the Antarctic Slope Front, in Jacobs, S.S., and Weiss, R.F., eds., Ocean, Ice and Atmosphere: Interactions at the Antarctic Continental Margin: Washington, DC, American Geophysial Union, p. 1-27.

Wood, S.E., and Askin, R.A., 1992, Dinoflagellate cysts from the Marambio Group (Upper Cretaceous) of Humps Island: Antarctic Science, v. 4, no. 3, p. 327-336.

Wrenn, J.H., and Hart, G.F., 1988, Paleogene dinoflagellate cyst biostratigraphy of Seymour Island, Antarctica, in Woodburne, M.O., and Feldmann, R.M., eds., The Geology and Paleontology of Seymour Island: Geological Society of America Memoir, v. 169, p. 321447.

Zinsmeister, W.J., 2001, Late Maastrichtian short-term biotic events on Seymour Island, Antarctic Peninsula: Journal of Geology, v. 109, p. 213-229.

\section{FIGURE CAPTIONS}

Figure 1. Location map of Seymour Island, Antarctica, using modern geography.

Figure 2. The abundance of key Maastrichtian palynomorphs from Seymour Island (this study), $\delta^{18} \mathrm{O}$ isotope values and key occurrences of macrofossils (Tobin et al., 2012;

Zinsmeister, 2001) and their interpretation regarding regional paleoclimate and possible sea ice presence. Timescale based on the correlation of magnetostratigraphy (Tobin et al., 2012) and strontium isotope stratigraphy (McArthur et al. 1998; Vonhof et al., 2011) to our section using the K/Pg boundary as a datum (updated to Gradstein et al., 2012). Age model verified using biostratigraphical data cited in Table DR2 and an iridium anomaly found at the $\mathrm{K} / \mathrm{Pg}$ boundary along strike (Elliot et al., 1994). Open arrow "a", Pycnodonte cf. P. vesiculosa (Sowerby 1823), 0 m (relative to K/Pg); open arrow “b”, Linotrigonia pygoscelium [Van - I 
522 could not find the author citation for this one - J], bivalve, $-200 \mathrm{~m}$; open arrow "c",

523 Dimitobelus seymouriensis, belemnite, -636 m (McArthur et al., 1998). Palynomorph events

524 A to J are discussed in the text. Photomicrograph, i, Impletosphaeridium clavus, D5.930.1A,

525 England Finder W65-1; ii, modern Islandinium? cezare, holotype, Saint-Césare, Quebec (SC

526 86-09, slide UQP 199-3B, B15-4; courtesy of Martin J. Head, Brock University). Brown

527 triangles and black dots denote the presence of fungal palynomorphs and pollen comparable

528 with modern angiosperm pollen from plants typical of warm, humid environments (Fig. DR1;

529 Table DR3). The snowflake symbols indicate particularly cold climatic episodes as

530 interpreted from the acmes of Impletosphaeridium clavus. *, Chenet et al. (2007, 2009);

531 Robinson et al. (2009).

532

533

534

535

${ }^{1}$ GSA Data Repository item 20xxxxx, Figure DR1, Tables DR1, DR2 and DR3, and

536 additional references are available online at www.geosociety.org/pubs/ft2009.htm, or on

537 request from editing@geosociety.org or Documents Secretary, GSA, P.O. Box 9140,

538 Boulder, CO 80301, USA. 